\title{
NOTE
}

\section{Virus-like particles and cytopathological effects in EIphidium excavatum clavatum, a benthic foraminiferan}

\author{
T. Heeger
}

SFB 313, University of Kiel, Olshausenstr. 40, D-2300 Kiel, Federal Republic of Germany

\begin{abstract}
Transmission electron microscopy gives first evidence of virus-like particles (VLP) in the cytoplasm of Elphidium excavatum clavatum from the western Baltic Sea. The particles are found mostly in groups or in microcrystalline arrays, in young chambers only. The VLP are about $100 \mathrm{~nm}$ in size, non-enveloped, containing an electron-dense core in a translucent intermediate capsid region. Based on digitalized area measurements, VLP-infected individuals are characterized by a significant increase in cytoplasmic vacuoles. Lipid inclusions are drastically reduced by $40.7 \%$ The role of foraminiferans as potential vectors of virus diseases of other aquatic organisms is discussed.
\end{abstract}

Foraminifera are Granuloreticulosa protozoans with agglutinated or calcified test inhabiting all marine environments. Viruses and virus-like particles (VLP) have rarely been found in protozoans and have never been reported from Foraminifera (Lauckner 1980). Franca (1976) described VLP of $35 \mathrm{~nm}$ in diameter in the flagellate Gyrodinium resplens from the west coast of Portugal. Teras et al. (1977) studied the interactions between several protozoans and virus types. No interactions occurred in $80 \%$ of those combinations, but particular protozoan species may be indifferent to viruses as far as inactivation or multiplication are concerned. Kesa \& Teras (1977) mentioned protozoans as possible potential sources of virus infections for aquatic animals. Viruses were found in Entamoeba histolytica and Plasmodium sp. (Nienhaus 1985) but were not classified by their morphology.

Individuals of Elphidium excavatum clavatum were collected in June 1987 from a $18 \mathrm{~m}$ deep station in the western Baltic Sea ( $54^{\circ} 32^{\prime}$ N, $10^{\circ} 25^{\prime}$ E), Federal Republic of Germany. They were fixed for $3 \mathrm{~h}$ in a solution of $2.5 \%$ glutaraldehyde in seawater, postfixed for $3 \mathrm{~h}$ in $2 \%$ osmium tetroxide and decalcified in $0.2 \mathrm{M}$ EDTA (ethylenedinitrilotetra acetate). After dehydration in a graded ethanol series, the specimens were transferred to propyleneoxide and ERL. Ultrathin sections were cut with a Reichert Ultracut E, stained with $1 \%$ uranylace- tate and $0.5 \%$ lead citrate. The sections were examined in a Siemens Elmiskop 101. The cytoplasmic compartments were area-measured with a cursor on a graphic table using a Zeiss digitalizer MOP 80 on an average of magnified micrographs $(30 \times 20 \mathrm{~cm})$. The micrographs were selected from 5 different ultrathin sections taken from each of 2 young virus-infected and 5 young noninfected chambers of $E$. excavatum clavatum.

The VLP are hexagonal in profile and measure 100 $\mathrm{nm}( \pm 3 \mathrm{~nm})$ between opposite vertices. The typical VLP is characterized by an electron-dense core of 65 $\mathrm{nm}$ in size and an electron-translucent intermediate region which is included in an icosahedral nonenveloped capsid (Fig. 1B). The occurrence of VLP is restricted to very young chambers. Attempts at detection of VLP in cytoplasm of other chambers were unsuccessful. The particles rarely appear singly, but mostly in groups attached to intracytoplasmic inclusions, or in microcrystalline arrays (Fig. 1A, C).

Digitalized measurements of cell compartments, based on micrographs of infected and non-infected foraminiferan individuals, indicate obvious morphological differences (Fig. 2A, B). In infected specimens, number and area of lipid inclusions are drastically reduced $\left(9.8 \mu \mathrm{m}^{2}\right)$ compared to non-infected individuals $\left(16.6 \mathrm{~mm}^{2}\right.$; Table 1). This tendency is much less pronounced and not significant for isolated chloroplasts. In contrast, area of cytoplasmatic vacuoles is significantly increased (31.4\%). Assuming that the results gained from investigations of non-infected specimens reflect a 'normal' condition, the mentioned morphological characteristics of infected individuals might indicate viral cytopathological effects. Pathological variations in test morphology of infected specimens could not be observed.

Elston (1979) found VLP-induced lesions in larval Pacific oysters, associated with electron-lucent vacuoles and intracytoplasmic inclusions in the velar 

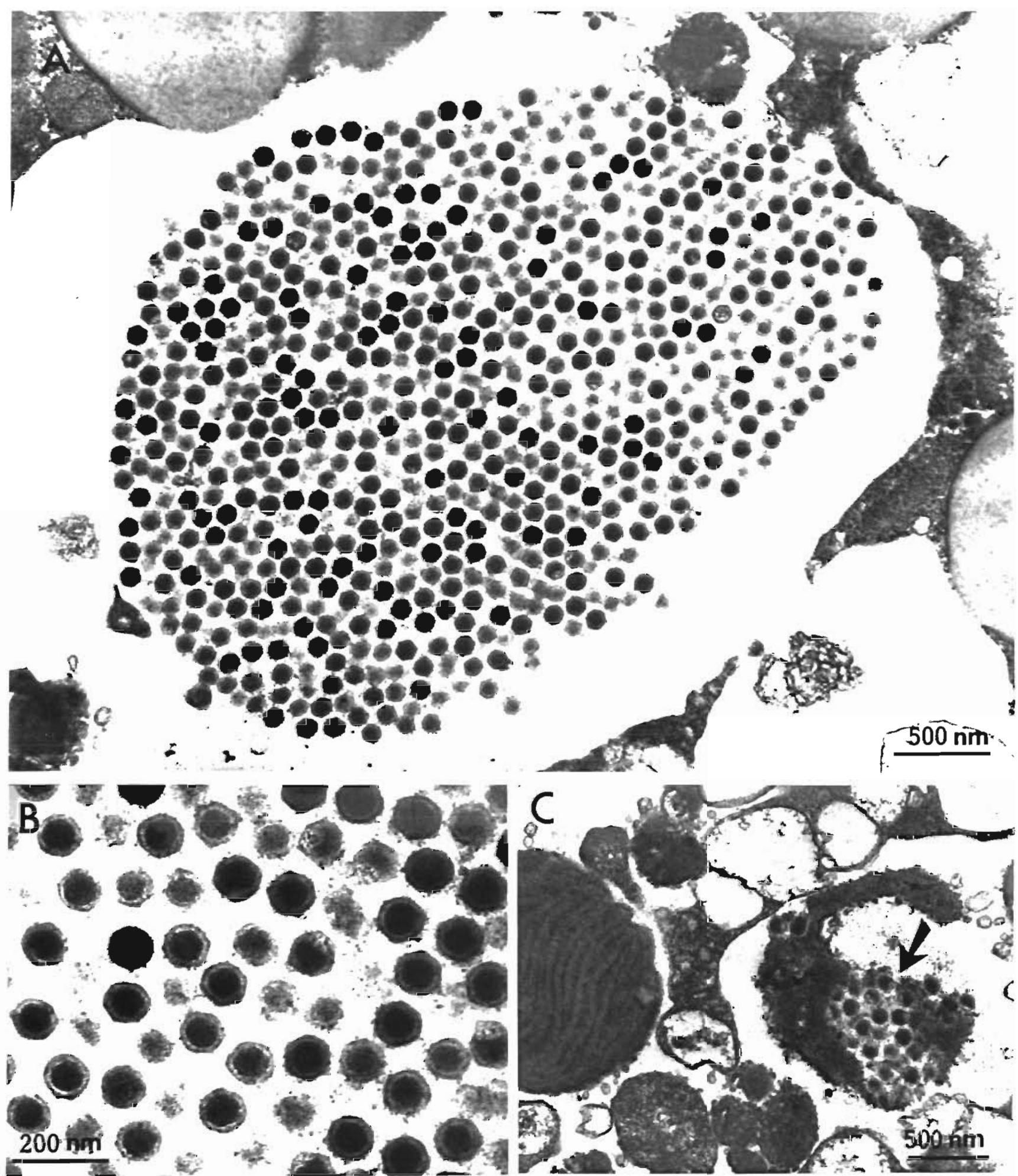

Fig. 1. Elphidium excavatum clavatum. Electron micrographs illustrating the presence of virus-like particles (VLP). (A) Microcrystalline array of iridovirus-like particles in a young chamber. (B) Magnification of (A); note the morphology of the nonenveloped, $17-\mathrm{nm}$-broad capsid layer of medium electron density and the osmiophilic dense core of $65 \mathrm{~nm}$ size. (C) Virions occur mostly in groups, close to intracytoplasmatic inclusions (arrow) 


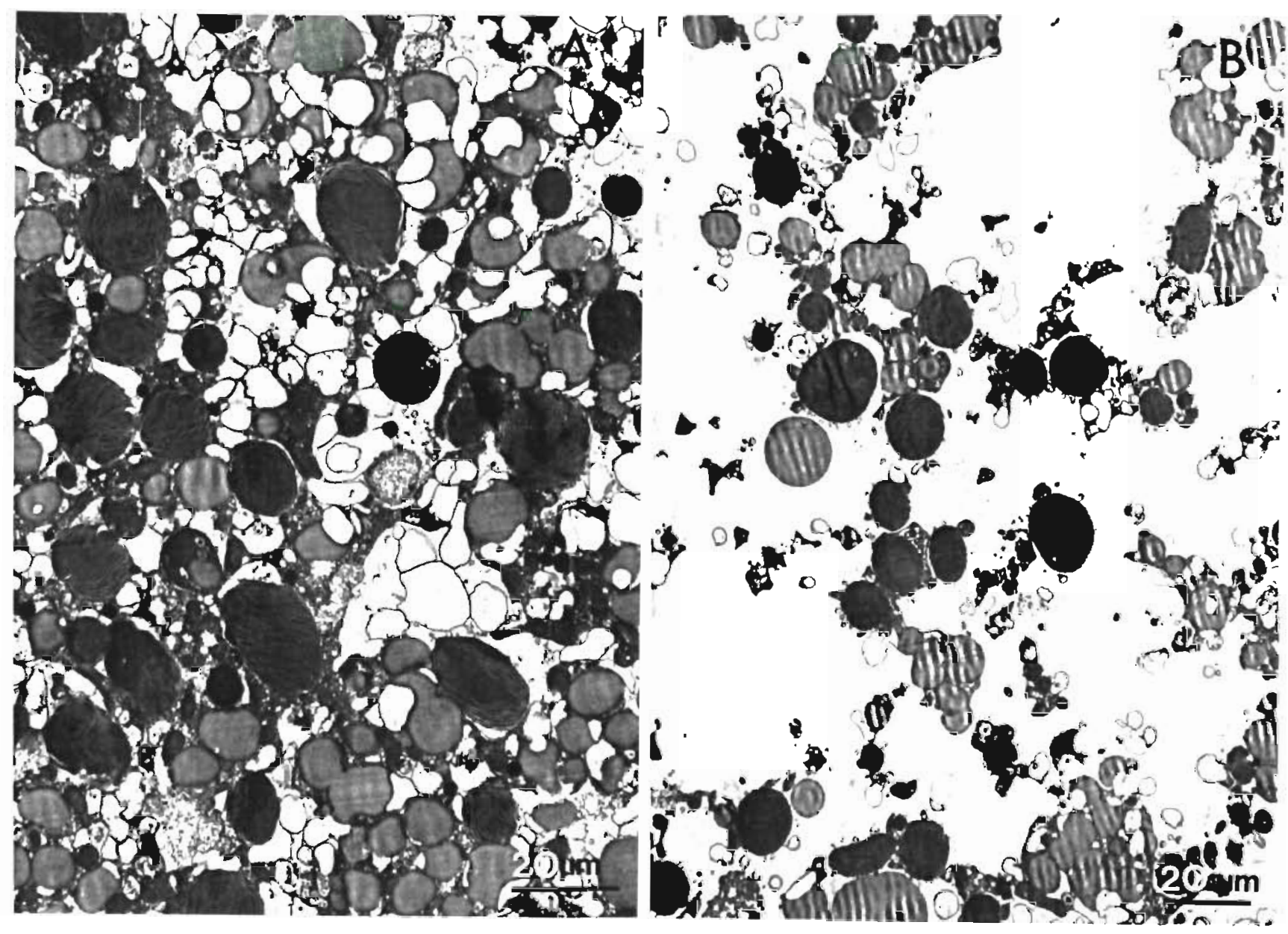

Fig. 2. Elphidium excavatum clavatum. Electron micrographs of ultrathin sections, demonstrating the different amounts of lipid inclusions, isolated chloroplasts and vacuoles in the cytoplasm of young chambers of (A) non-infected and (B) VLP-infected foraminiferans

Table 1 Elphidium excavatum clavatum. Comparative area measurements of cytoplasmic compartments in virus-infected and non-infected foraminiferans standardized to $100 \mathrm{\mu m}^{2}$ Numbers derived from 5 magnified micrographs each, of 2 virus-infected and 5 non-infected individuals (standard deviation in brackets)

\begin{tabular}{|lccc|}
\hline & $\begin{array}{c}\text { Lipid } \\
\text { inclusions } \\
\left(\mu \mathrm{m}^{2}\right)\end{array}$ & $\begin{array}{c}\text { Isolated } \\
\text { chloroplasts } \\
\left(\mu \mathrm{m}^{2}\right)\end{array}$ & $\begin{array}{c}\text { Vacuoles } \\
\left(\mu \mathrm{m}^{2}\right)\end{array}$ \\
\hline $\begin{array}{l}\text { Infected } \\
\text { cytoplasm }\end{array}$ & 9.8 & 11.9 & 61.4 \\
Non-infected & $(2.5)$ & $(1.4)$ & $(3.5)$ \\
cytoplasm & 16.6 & 12.8 & 42.1 \\
$\begin{array}{l}\text { Difference } \\
(\%)\end{array}$ & $40.4)$ & $(1.8)$ & $(5.2)$ \\
\hline
\end{tabular}

epithelium only. Pathological changes of host cell lysosomes and their loss of content as a cellular response were observed by Liversidge et al. (1985).
Average size, morphology and the occurrence of typical microcrystalline arrays suggest an iridovirus infection (Devauchelle et al. 1985). Iridoviruses reported so far were characterized as icosahedral particles ranging from 120 to $300 \mathrm{~nm}$ in size and containing double-stranded DNA. The size difference (20 nm) between the described particles (100 nm) and the reported range is possibly an artifact of cell fixation and sectioning, so many values published for iridoviruses are probably not comparable. The group includes several viruses from invertebrates (Devauchelle 1977), amphibians (Goorha \& Granoff 1979) and fish (Möller \& Anders 1986). The best-studied iridovirus is lymphocystis disease virus of fish, which has been recorded to date in 137 species of teleost fish (Anders in press).

As area counts of different cell compartments were derived from a limited number of sections and individuals, while the physiological state at the time of fixation is unknown, the results should be interpreted 
with caution. The high standard deviation (Table 1) supports this view Further studies with infected cultured foraminiferans are necessary to prove the cytopathological effects.

More than 4000 recent species of Foraminifera distributed worldwide in marine environments indicate their potential importance for virus diseases. Ahne (1985) discussed the introduction of pathogenic fish viruses by plankton into aquaculture facilities. High biomass values of living Foraminifera illustrate the possible carrier and vector function of disease agents of other aquatic organisms.

Acknowledgements. The author is grateful to Prof. Dr S. A. Gerlach, Prof. Dr W Ahne, Dr K. Anders and Dipl. Biol. P. Linke for critical reading of the manuscript. This study was supported by the Deutsche Forschungsgemeinschaft and is publication No. 52 of Sonderforschungsbereich 313 .

\section{LITERATURE CITED}

Ahne, W (1985). Zum Risiko der Einschleppung fischpathogener Viren mit Wasseroganismen. Der Fischwirt 9: 61-63

Anders, K. (in press). Lymphocystis disease. In: Horzinek, M. C. (ed.) Viral infections of vertebrates, Vol. 7, Viral infections of fish and other poikilotherms. Elsevier, Amsterdam

Devauchelle, G. (1977). Ultrastructural characterization of an iridovirus from the marine worm Nereis diversicolor $1 \mathrm{O} . \mathrm{F}$ Müller). Virology 81: $237-246$
Devauchelle, G., Stoltz, D. B., Darcy-Tripier, F. (1985). Comparative ultrastructure of iridoviridae. In: Willis, D B (ed.) Current topics in microbiology and immunology, Vol. 116. Springer-Verlag, Heidelberg, p. 1-21

Elston, R (1979). Virus-like particles associated with lesions in larval Pacific oysters (Crassostrea gigas). J. Invertebr Pathol. 33: 71-74

Franca, S. (1976). On the presence of virus-like particles in the dinoflagellate Gyrodinium resplens (Hulbert). Protistologica 12: 425-430

Goorha, R., Granoff, A. (1979). Icosahedral cytoplasmic deoxyriboviruses. In: Fraenkel-Conrat, H., Wagner, R. R. (eds.) Comprehensive virology: newly characterized vertebrate viruses. Plenum Press, New York, London, p. 347-544

Kesa, L., Teras, J. (1977). Pathogenicity of free-living Protozoa in interaction with viruses in vitro. (Abstract) In: Proceedings of the 5th International Congress of Protozoology, New York, No. 126

Lauckner, G. $\{1980\}$. Diseases of Protozoa. In. Kinne, O. (ed.) Diseases of marine animals, Vol. I. General aspects, Protozoa to Gastropoda. Wiley \& Sons, Chichester, p. 75-127

Liversidge, J., Munro, A. L. S., Schlotfeldt, H. J., Evelyn, T P. T (1985). Fischpathogene Viren. In: Roberts, R. J., Schlotfeldt, H. J. (eds.) Grundlagen der Fischpathologie. PareyVerlag, Hamburg, p. 112-173

Möller, H., Anders, K. (1986). Diseases and parasites of marine fishes. Möller, Kiel

Nienhaus, F. (1985). Viren, Mykoplasmen und Rickettsien. UTB-Verlag, Stuttgart

Teras, J., Kesa, L., Kallas, E., Jogiste, A. (1977). On the relationship between some free-living and parasitic Protozoa and the RNA and DNA viruses. (Abstract) In: Proceedings of the 5th International Congress of Protozoology, New York, No. 446 